\title{
C02 急拡大空間を有するパルス管エンジンの基本特性
}

\section{Basic Characteristics of a Pulse Tube Engine with a Sudden Expansion Space}

\author{
○藤井 俊輔 (明星大・院), 正 濱口 和洋 (明星大), 矢崎 太一(愛教大)
}

Shunsuke FUJII, Kazuhiro HAMAGUCHI, Meisei University, Hodokubo, Hino, Tokyo

Taichi YAZAKI, Aichi University of Education, Hirosawa, Igaya-cho, Kariya, Aichi

\begin{abstract}
The pulse tube engine consists of one piston in one cylinder, cooler with orifice, pulse tube, heater and gas damper with stacked wire gauzes. The pulse tube has the work source in this engine. The gas damper has the function breaking the thermodynamic symmetry. For this research, the engine replaced a gas damper with a sudden expansion tube is proposed. A simple prototype engine, using air at normal atmospheric pressure as the working gas, was fabricated. Effects of expansion tube shape on the engine performance were examined experimentally. The effect of sudden expansion tube was confirmed.
\end{abstract}

Key words: thermoacoustic engine, gas damper, sudden expansion space, shaft power

\section{1. 緒 言}

著者らの提案したパルス管エンジン(1)は, 1シリンダ1ピストン, オリフィスの機能も有するクーラ, パルス管, ヒータ, そして積層 金網を挿入したガスダンパにより構成され，1ピストンにより出力 を取り出すことができる。ガスダンパは, 熱力学的な対称性を破 る役割を果たすと考えられ，同様の役割を担う一つの方法とし てパルス管と断面径の大きく異なる拡大管の利用も考えられて いる(2)。本報では, 従来のガスダンパ型と拡大空間型の両モデ ルエンジンを製作し, 実験的に両エンジン性能の比較を行うと ともに拡大空間寸法のエンジン性能への影響を検討する。

\section{2. 実験エンジン及び実験方法}

従来のガスダンパ型パルス管エンジンの構成を図1(a), そして図 1 (a)のガスダンパを拡大管に置き換えた拡大空 間型パルス管エンジンを図 1 (b)に示す。両エンジンとも, ヒータ部には伝熱促進のため20メッシュのステンレス鋼 金網積層体を挿入している。外部からの加熱にはシースヒ 一タを用い，ヒータ部の熱漏えいを防ぐため断熱材で覆う。 その加熱量は30W一定である。クーラ部はオリフィスも兼 ね，冷却方法は自然空冷である。ピストン直径は $\phi 15 \mathrm{~mm}$, ストロークは $43 \mathrm{~mm}$ ，そして作動ガスには大気圧空気を使 用する。熱力学的な非対称状態を創り出すガスダンパ部は 50メッシュのステンレス鋼金網積層体である。また，拡大 空間部は直径 $\mathrm{D}=\phi 28 \mathrm{~mm}, \phi 37 \mathrm{~mm}, \phi 46 \mathrm{~mm}$ の円管を選 び, その長さLは, 直径Dにより異なるが $10 〜 60 \mathrm{~mm}$ とする。 本エンジンの性能計測システムを図 2 に示す。

軸出力の測定には直流電気動力計方式を採用する。出力

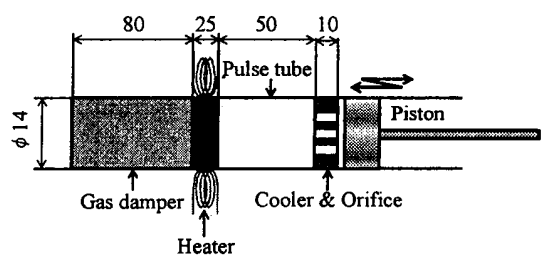

(a) Pulse tube engine with gas damper

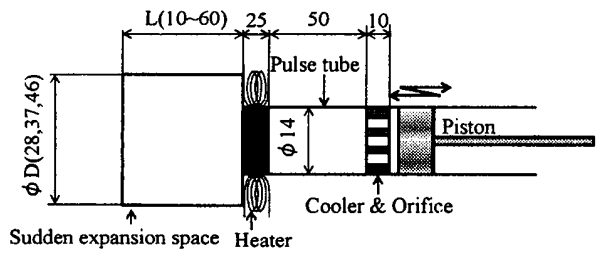

(b) Pulse tube engine with sudden expansion space Fig.1 Pulse tube engine
軸には小型直流モータを取り付け，そのモータに負荷を与 えた結果生じる反力を電子上血天称により測定し，同時に 測定する回転数を用いて軸出力に換算する。作動ガス温度 は，ガスダンパ端もしくは拡大空間端，ヒータとクーラ内 部の 3 箇所をK型熱電対, そして外部熱源温度も $\mathrm{K}$ 型熱電 対により測定する。作動ガス圧力はガスダンパ端もしくは 拡大空間端, オリフィス内部の 2 箇所を半導体圧カセンサ により測定し, 直流増幅器及びデータロガーを介してPC に取り込む。それと同時にクランク角も出力軸に取り付け たエンコーダにより取り込み，データ処理に用いる。

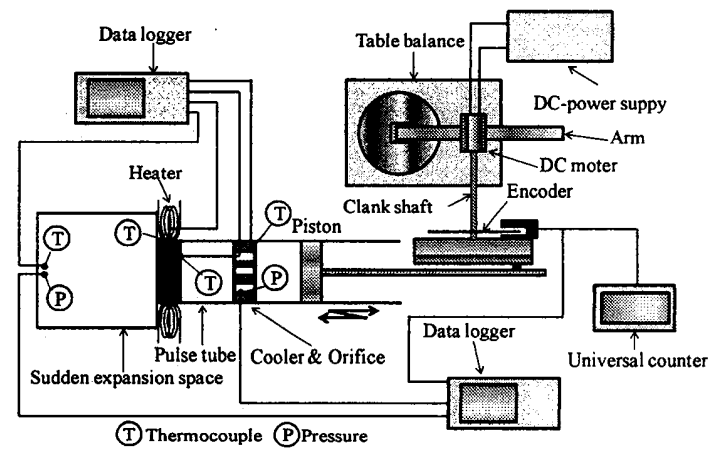

Fig.2 Experimental apparatus

\section{3. 実䀦結果}

\section{1 ガスダンパ型エンジンの性能特性}

図 3 にガスダンパ型エンジンにおいて最も高い軸出力 $78 \mathrm{~mW}(442 \mathrm{rpm})$ の得られたP-V線図を示す。このときのヒ 一タ空間温度は $260^{\circ} \mathrm{C}$, クーラ空間温度は $35^{\circ} \mathrm{C}$ あ゙る。図 4 にガスダンパ型エンジンの性能曲線を示す。同図より, 図示出力は回転数の増加に伴い増加しているが，軸出力は 450rpm付近までは回転数の増加に伴い増加するものの, それ以降は減少している。これは回転数の増加に伴う作動 ガスの流動抵抗並びに機械損失の増加が原因と考えられ

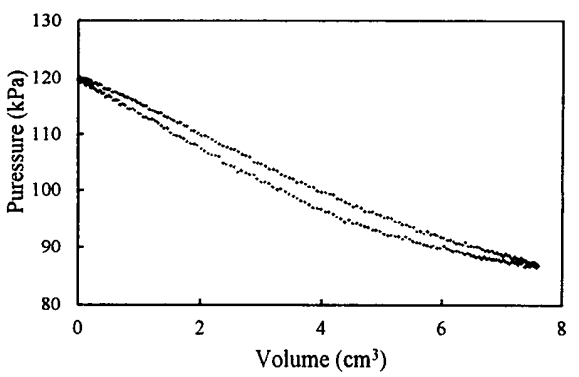

Fig.3 P-V diagram of pulse tube engine with gas damper(450rpm) 


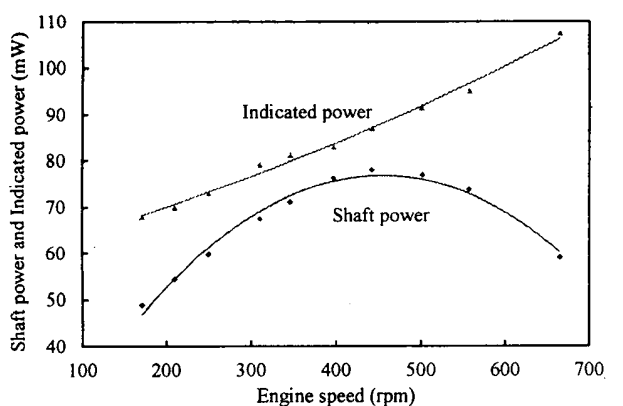

Fig.4 Performance of pulse tube engine with gas damper

る。ガスダンパ端とオリフィスで得られた最高圧力時のク ランク角度の差（位相角）は，最高軸出力時に最も大きく $9.2 \mathrm{deg}$.ある。

\section{2 拡大空間型エンジンの性能特性}

拡大空間型エンジンでは, 実験結果の評価にあたり, 拡 大空間型の断面積比AR及び容積比VRを用いる。断面積比 AR及び容積比VRは次式により定義する。

$$
\begin{aligned}
& \mathrm{AR}=\left(\frac{\mathrm{D}}{\mathrm{d}}\right)^{2} \\
& \mathrm{VR}=\frac{\mathrm{V}_{\mathrm{E}}}{\mathrm{V}_{\mathrm{S}}}
\end{aligned}
$$

ここで，Dは拡大空間直径，dはパルス管直径， $V_{\mathrm{E}}$ は拡大空 間部容積, $V_{\mathrm{S}}$ はピストンの行程容積である。なお, 本実験 で使用した急拡大管の各断面径Dにおける断面積比AR及 び各断面径において設定した長さLにおける容積比VRを 表 1 に示す。

Table 1 Dimensions of sectional area ratio and volume ratio

\begin{tabular}{|c|c|c|c|}
\hline$\phi \mathrm{D}(\mathrm{mm})$ & AR & $\mathrm{L}(\mathrm{mm})$ & $\mathrm{VR}$ \\
\hline 28 & 4 & $10 \sim 60$ & $2.42 \sim 4.85$ \\
\hline 37 & 7 & $20 \sim 35$ & $2.82 \sim 4.95$ \\
\hline 46 & 10.4 & $12.5 \sim 30$ & $2.7 \sim 6.47$ \\
\hline
\end{tabular}

図 5 に，拡大空間型エンジンにおいて最も高い軸出力 $38.1 \mathrm{~mW}(350 \mathrm{rpm})$ の得られたP-V線図を示す。このときの

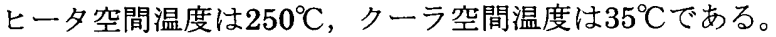
その拡大空間は, 断面積比 $\mathrm{AR}=4$, 容積比 $\mathrm{VR}=3.72$ を有し ている。同図と図 3 を比較すると，拡大空間型はガスダン パ型に比べ, 圧力振幅, 膨らみともに小さいことがわかる。 図 6 に図 5 と同一の拡大空間寸法を有する拡大空間型工 ンジンの性能曲線を示す。図示出力は, 回転数の増加に伴 い増加している。これに対して，軸出力は350 rpm付近ま では増加しているが，それ以降は減少している。これも流 動抵抗並びに機械損失の影響と考えられる。なお，最高軸 出力時の位相角は $6.5 \mathrm{deg}$.である。図 6 と図 4 を比較すると, 拡大空間型はガスダンパ型に比べ, 回転領域が狭く, 最高 軸出力は約 $50 \%$ 程度であった。これは，容積比VRがエン ジン性能に影響している。容積比VRはガスダンパ型が 1.1, 拡大空間型が3.72であり, 拡大空間型はガスダンパ型に比 べ3倍以上である。両空間は, 無効容積にもなることから, 位相角への影響よりも圧力振幅, ひいてはエンジン性能に 大きく影響を及ぼしたと考えられる。また，最高軸出力時 の位相角も拡大空間型はガスダンパ型に比べ約3deg.低い。

図7に断面積比を $\mathrm{AR}=4 ， 7 ， 10.4$ と一定にした場合の容 積比VRの各最高軸出力への影響を示す。同図より, 各断面 積比 $\mathrm{AR}$ における最高軸出力は, 容積比 $\mathrm{VR}=3.7$ 付近まで増 加するが，それ以降は減少している。これは無効容積が大 きく影響していると考えられる。なお, 各断面積比ARの最
高軸出力は, 容積比 VR=3.7 付近において得られていること から, 拡大空間部の断面積比ARの影響は少ないものと思わ れる。これは; 拡大空間形状のエンジン性能への影響は, 断面積比よりは容積比すなわち拡大空間容積が，大きく影 響していることを示す。

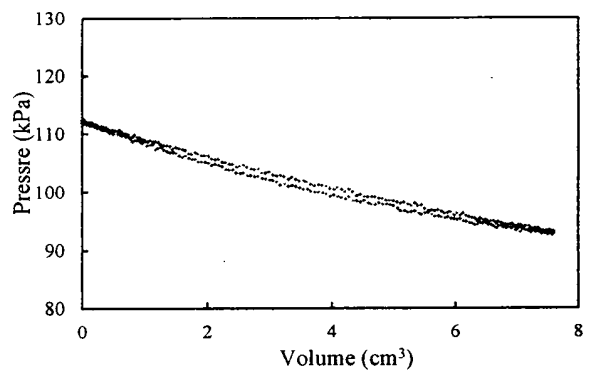

Fig.5 P-V diagram of pulse tube engine with sudden expansion space(350rpm)

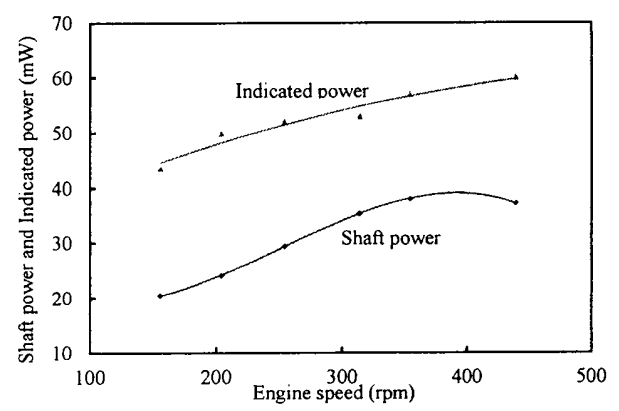

Fig.6 Performance of pulse tube engine with sudden expansion space

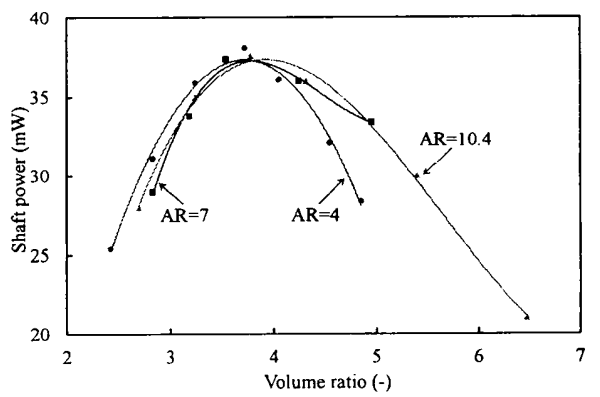

Fig.7 Effect of sectional area ratio and volume ratio on shaft power

\section{4. 結 言}

積層金網を用いるガスダンパに対して単なる拡大空間 のみのパルス管エンジンの基本特性を実験的に調べると ともに両者を比較した結果，以下のことがわかった。 (1)拡大空間型エンジンの動作が確認できたが, その軸出 力はガスダンパ型エンジンの約 $50 \%$ であった。これは, 無効容積にもなる拡大空間容積が大きく影響している。 (2)拡大空間型エンジンの性能は, その断面径よりも空間 容積に大きく影響される。

\section{文 献}

(1) Hamaguchi, K., Futagi, H., Yazaki, T. and Hiratsuka, Y., "Measurement of Work Generation and Improvement in Performance of a Pulse Tube Engine", Journal of Power and Energy Systems, JSME, Vol.2,No.5(2008), pp1267-1275.

(2)吉田隆昌, 矢崎太一, 濱口和洋, 琵琶哲志, パルス管 エンジンにおうける仕事流束密度測定, 低温工学, Vol47, No.1, (2012), pp52-57. 